\title{
INVESTIGATING THE INFLUENCE OF CUTTING SPEED ON THE TOOL LIFE OF A CUTTING INSERT WHILE CUTTING DIN 1.4301 STEEL
}

\author{
PREISKAVA VPLIVA HITROSTI REZANJA NA ZDRŽLJIVOST \\ VLOŽKA ZA REZANJE PRI REZANJU JEKLA DIN 1.4301
}

\author{
Rozmarína Dubovská ${ }^{1}$, Jozef Majerík ${ }^{2}$, Robert Čep $^{3}$, Karel Kouřil ${ }^{4}$ \\ ${ }^{1}$ University of Hradec Kralove, Faculty of Education, Department of Technical Subjects, Rokitanského 62, \\ 50003 Hradec Králové, Czech Republic \\ ${ }^{2}$ Alexander Dubcek University of Trencin, Faculty of Special technology, Department of Engineering, Pri Parku 19,91105 Trenčín, Slovakia \\ 3Technical University of Ostrava VŠB, Faculty of Mechanical Engineering, Department of Machining and Assembly, 17.listopadu 15, \\ 70833 Ostrava, Czech Republic \\ ${ }^{4}$ Brno University of Technology, Faculty of Mechanical Engineering, Institute of Manufacturing Technology, Technická 2896/2, \\ 61669 Brno, Czech Republic \\ robert.cep@vsb.cz
}

Prejem rokopisa - received: 2015-02-10; sprejem za objavo - accepted for publication: 2015-05-20

doi: $10.17222 / \mathrm{mit} .2015 .036$

\begin{abstract}
The main aim of this paper is to assess the tool life $T=f\left(v_{\mathrm{c}}\right)$ during the dry turning of 1.4301 austenitic stainless steel with a CNMG 120408 coated carbide cutting insert. Experimental tests of the selected material were realized in an Aero Turn BT-380 CNC machine tool with a Fanuc 21i TB control system. The effect of the applied cutting parameters on the surface finish, tool wear, tool life and surface roughness were investigated during the realized experiments. The aim of the present paper is to focus scientific research on the impact of the various cutting speeds during the outer longitudinal turning. The presented approach and results will be helpful for understanding the machinability of 1.4301 austenitic stainless steel during dry turning. This paper, together with the achieved results, is a basis to optimize the performance of the machining (i.e., turning) of austenitic stainless steel 1.4301 used for special industrial applications with their dominant functional areas.

Keywords: austenitic stainless steel, CNC turning, cutting speed, tool life, surface finish
\end{abstract}

Glavni namen članka je oceniti preiskovano zdržljivost orodja $T=f\left(v_{\mathrm{c}}\right)$ pri struženju, brez mazanja avstenitnega nerjavnega jekla 1.4301, s karbidnim rezalnim vložkom CNMG 120408 s prevleko. Preizkusi izbranega materiala so bili izvršeni na CNC stroju Aero Turn BT-380 s Fanuc 21i TB kontrolnim sistemom. Med preizkusi je bil preiskovan vpliv uporabljenih parametrov pri rezanju na kvaliteto površine, obrabo orodja, zdržljivost orodja in hrapavost. Namen članka je usmeriti raziskavo na vpliv različnih uporabljenih vrednosti hitrosti rezanja pri zunanjem vzdolžnem struženju. Vsi predstavljeni približki in rezultati bodo pomagali pri razumevanju obdelovalnosti avstenitnega nerjavnega jekla 1.4301 pri struženju brez mazanja. Dobljeni rezultati so osnova za optimiranje struženja avstenitnega nerjavnega jekla 1.4301, ki se ga, na podlagi posebnih lastnosti, uporablja pri posebnih industrijskih namenih.

Ključne besede: avstenitno nerjavno jeklo, CNC struženje, hitrost rezanja, zdržljivost orodja, kvaliteta površine

\section{INTRODUCTION}

High productivity and reliability are necessary in today's very highly competitive world of production. In this context, the appropriate selection of cutting tool geometry and tool material is crucial to be competitive, especially in the field of difficult-to-machine materials, such as stainless steels. ${ }^{1,2}$ Problems such as poor surface finish and high tool wear are common in the machining of austenitic stainless steel. The authors ${ }^{3}$ carried out turning tests on the 1.4301 austenitic stainless steel to determine the optimum machining parameters. Austenitic stainless steel is among the difficult-to-cut material and difficulties such as poor surface finish and rapid tool wear are common..$^{4-8}$ Stainless steels are widely used in several industrial sectors, such as engine production, the medical and chemical industries. Their high strength, low thermal conductivity, high ductility and high tendency towards work hardening are the main factors for their poor machinability. ${ }^{9}$ The turning of parts made of austenitic stainless represents nearly $24 \%$ of all machined parts made of steel. Various special chemical compositions of stainless steels are a challenge for all machining technologies. High-speed machining (HSM) is applied with significantly higher cutting speeds $v_{\mathrm{c}}$ with relatively small cross-sections being cut. HSM techno$\operatorname{logy}$ is realized with extremely hard and heat-resistant cutting tools. ${ }^{10}$ With the trend in technology development, stainless steel has been broadly adopted because it has the characteristics of high toughness, low thermal conductivity, and a high strain hardening coefficient. This has a negative effect on the surface finish of a machined product and results in a reduced tool life. ${ }^{11}$ Such is the case for austenitic stainless steels, which in spite of being materials of high economic and technological value, their behaviour with respect to machining is still not well understood in some aspects. There are 
not reliable and updated technological data about austenitic stainless steels in industry. ${ }^{12}$ The austenitic stainless steel AISI 304 (according to DIN 1.4301) is the second most widely used anti-corrosive material with excellent corrosion resistance, cold formability and weldability. The steel 1.4301 is resistant to water, steam, humidity, edible acids, weak organic and inorganic acids. ${ }^{13}$ Austenitic stainless steel is not hardenable. However, its strength can be increased by cold forming. It is characterized by the need for a solution treatment to ensure corrosion resistance in contact with a wide range of substances. The AISI 304 is approved for a thermal stress of $300{ }^{\circ} \mathrm{C}$. When machining the 1.4301 it is necessary to work with sharp cutting tools of high-speed alloyed steel or cemented carbides because of the tendency to harden. The steel 1.4301 (AISI 304) is used in the engineering and nuclear industries, in architecture, in transport facilities, the food industry, the pharmaceutical and cosmetic industries, the construction of chemical apparatus and vehicles, the manufacture of surgical instruments, sanitary installations, objects and appliances and works of art. The shape of the individual components for the automotive industry and subsequently the time and relative complexity of the conversion work and tool paths for CNC (Computer Numerical Control) program preparation led to the establishment of internal and external graphics support for the creation of individual programs. ${ }^{14} \mathrm{CNC}$ machines are commonly used in automated factories for producing machined parts. In this study, the AISI 304 austenitic stainless steel was used to help the manufacturers. In this work, the values for the flank wear were investigated and in this way the best cutting parameters were determined. Apart from classic methods, it was also investigated that the process sound generated during machining could be used to assess machinability. ${ }^{15}$ Surface integrity is an important factor in evaluating the machinability of the steels. ${ }^{16}$ Numerous experimental investigations have been carried out over the years to study the effect of the cutting parameters and tool geometries on the workpieces' surface integrity using several types of workpiece materials. ${ }^{17}$ Currently, companies prefer to order material according to DIN or AISI.

\section{MATERIALS AND METHODS}

The basic factor that causes the flank wear of carbide tools is the high temperature of the cutting edge. In order to increase tool life, we have to reduce this temperature. For machining is necessary to use a stable and solid CNC machine tool with the appropriate cooling. The workpiece material and cutting tools must be firmly clamped in the CNC machine with a small overhang. It is important to create the conditions for cutting, to prevent the formation of vibrations. Progressive solutions in terms of cutting tools seem to be new cutting materials for machining stainless, especially austenitic, steels.
There are cutting tools with changeable cutting inserts with a fine-grained or ultrafine-grained substrate. The carbide grain size is from $0.3 \mu \mathrm{m}$ to $0.5 \mu \mathrm{m}$. On the cemented carbide is deposited a multilayer with the coatings type $\mathrm{TiC}+\mathrm{Al}_{2} \mathrm{O}_{3}+\mathrm{TiN}$ on the surface, the substrate is $\mathrm{WC}+\mathrm{Co}$. The austenitic stainless steels are generally annealed for austenitizing, so that they are heated to $1000-1150{ }^{\circ} \mathrm{C}$. Subsequently, they are quickly cooled in water or air, to prevent the precipitation of the carbides at the grain boundaries. This resulted in a homogeneous austenitic structure. The structure increases with the resistance of these steels to intergranular corrosion and the metallurgical point of view is correct. The disadvantage is a significant increase in the ductility and plasticity of these steels, which is highly undesirable during operation. From the metallurgical point of view, the distinguishing feature of poor machinability is the kinematic coarse austenite, almost carbides. The sign of good machinability is a fine-grained austenite with plenty of finely distributed carbides. Machinability is related to the economy of production. The aim is to produce the maximum performance with the available resources. Machinability influences and even determines the cutting forces, heat and cutting temperature, chip formation, wear and tool life, but also the surface integrity. Cutting parameters such as the cutting speed $v_{\mathrm{c}}$ and the feed rate $f$ play critical roles in the cutting temperature and the surface roughness in the turning processes. The surface roughness, which is used for the evaluation of the product quality, is an important performance characteristic in turning processes. ${ }^{18}$ That is, cutting speeds out of the range recommended by tool manufacturers (cutting speed in the range of $v_{c}=180-250 \mathrm{~m} \mathrm{~min}^{-1}$ ) were tested. The objective was to analyse the effect of cutting speed over the work material-toolpair. ${ }^{19}$ I. Korkut et al. ${ }^{19}$ and I. Ciftci et al. ${ }^{20}$ reported that during the turning of AISI 304 austenitic stainless steel using a multilayer (CVD) coated tool, the tool flank wear decreases with an increasing cutting speed up to $180 \mathrm{~m} \mathrm{~min}^{-1}$ and the surface roughness values decrease with the increasing the cutting speed. The poor performance of the tool at lower cutting speeds can be explained by the influence of the heat on the cutting tool. That is because, metal cutting involves the generation of a large amount of heat and in the machining of AISI 304 stainless steel it is not dissipated rapidly due to the low thermal conductivity of this material. The heat generation principally occurs in three areas: the shear zone, the rake face and on the clearance side of the cutting edge. ${ }^{20} \mathrm{~W}$. Grzesik et al. ${ }^{21}$, studied the machinability of AISI 304 and C45 steel using CVD TiC, TiN/ TiC and $\mathrm{TiN} / \mathrm{Al}_{2} \mathrm{O}_{3} / \mathrm{TiC}$ coated and uncoated (P20) cemented carbide tools. They found that in the case of $\mathrm{TiC}$ and $\mathrm{TiN} / \mathrm{Al}_{2} \mathrm{O}_{3} / \mathrm{TiC}$ coating the specific cutting pressure decreases and for the TiC/TiN coating it increases. In another study they found a low value of the surface roughness for the coating $\mathrm{TiC} / \mathrm{Al}_{2} \mathrm{O}_{3} / \mathrm{TiN}$. In addition, they found that as the 
cutting speed increases the cutting force and the contact length decreases. A. Hosokawa et al. ${ }^{22}$ reported that during its own realization of turning tests of stainless steel (AISI 304) were carried out in order to examine the tool-wear characteristics. W. I. H. Liew ${ }^{23}$ investigated the wear characteristics of PCBN (polycrystalline cubical boron nitride) tools in the ultra-precision machining of stainless steel. ${ }^{22}$ During lathe turning, the machined surface is work hardened. This work-hardened surface is machined on the next lathe turning step, which accelerates the tool wear. ${ }^{23}$ This results in the degradation of the surface quality and the acceleration of the adhesive wear of the tools used. ${ }^{24}$ All of these experiments determine that the purpose and the machinability significantly affect the cutting process. The machining of highstrength materials can cause brittle fracture of the cutting edge parts. This is due to the high cutting forces during machining. In a practical assessment of the size of the wear it is most common to use parameters such as the width of the wear pads on the back of the $V B_{k}$ and the depth of the groove at the forefront of the $K T$ (according to ISO 3685). The intensity of the wear may affect the cutting conditions. The biggest influence is the cutting speed, then the feed rate and a smaller minimum is the depth of cut. When turning austenitic stainless steels, they are a generally chosen criterion of the flank wear $V B_{\mathrm{k}}$, given the increase in cutting forces with increasing wear. There is also an increase in the temperature and the intensity of the wear of the cutting tool. The duration of the work of the cutting tool with a target of $V B_{\mathrm{k}}$ wear, the tool life $T$ can be determined within minutes of the machining time, the number of machined parts or the cutting tool path. The cutting tool's ability to restore its sharpness or setting a new cutting edge with a cutting tool exchange. In practice we try to choose the criterion of wear, so that we have the maximum tool life. Selection criteria and the process limits the wear and machined surface roughness achieved, increased cutting

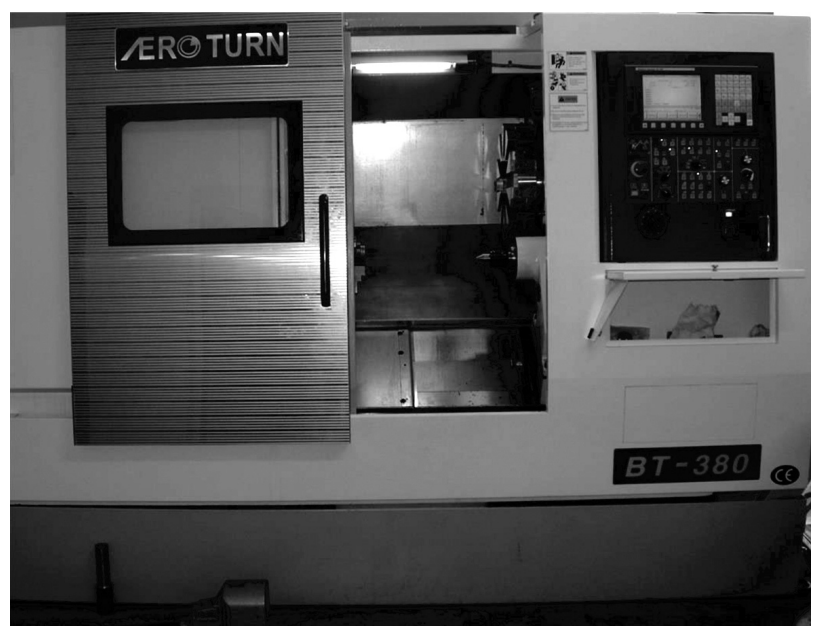

Figure 1: Overall view of the AERO TURN BT-380 CNC machine tool

Slika 1: Izgled CNC stružnice AERO TURN BT-380 forces, and the emergence of oscillations in the system's working. We are talking about the technological criterion of wear. The tool life depends on the cutting conditions, the geometry of the cutting wedge-shaped tools, the cutting material, the fluency of the cutting process, the method and type of operation and the workpiece material.

\section{EXPERIMENTAL DETAILS}

The main aim of the paper was the measurement of the tool life $T=f\left(v_{\mathrm{c}}\right)$ for various cutting speeds. The experiments were performed in the tool AERO TURN BT-380 CNC machine (Figure 1) with a maximum spindle speed $n_{\max }=4500 \mathrm{~min}^{-1}$ and performance $P_{\mathrm{c}}=$ $11.5 \mathrm{~kW}$ with a turret for clamping the cutting tools (Figure 2) and a CNC control system FANUC Series 0i - TC. The workpiece material was austenitic stainless steel 1.4301(microstructure can be seen in Figure 3), Ø $60 \mathrm{~mm} \times 200 \mathrm{~mm}$, hardness HB 190. The clamping was in a three-jaw chuck with the turned inside diameter $\varnothing 60 \mathrm{~mm}$ in length $l=15 \mathrm{~mm}$, clamping the workpiece by the tail stock. The cutting tool was a side cutting tool holder $\kappa_{\mathrm{r}}=95^{\circ}$, with geometry PCLNR 2525 (PRAMET Tools). The carbide cutting insert was CNMG 120408E-NM, carbide type GC 2025 (PRAMET Tools), used for rough machining of the austenitic stainless steels (SEM microstructure of cutting edge's appearance can see in Figure 4).

Cutting conditions:

- Depth of cut $a_{\mathrm{p} 0}=1.0 \mathrm{~mm}$,

- Feed rate $f_{0}=0.15 \mathrm{~mm} / \mathrm{rev}$,

- Cutting speed $v_{\mathrm{c} 1}=250 \mathrm{~m} \mathrm{~min}^{-1}, v_{\mathrm{c} 2}=200 \mathrm{~m} \mathrm{~min}^{-1}$, $v_{\mathrm{c} 3}=150 \mathrm{~m} \mathrm{~min}^{-1}$ with usage of the coolant $\mathrm{E} 5 \%$.

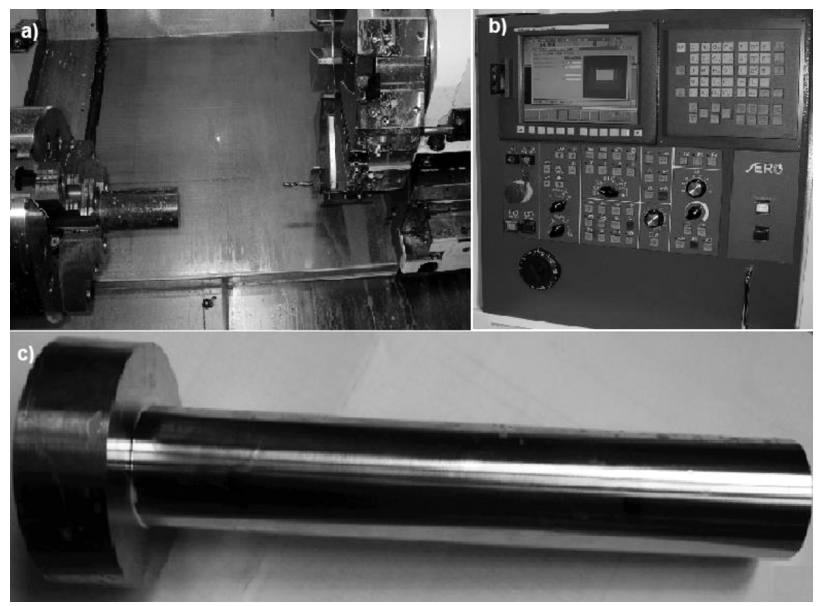

Figure 2: a) Cutting area of $\mathrm{CNC}$ machine tool with clamped workpiece, b) control panel of the AERO TURN BT-380 CNC machine tool with system FANUC Series 0i - TC, c) view of the workpiece (tested part) used for the turning experiments

Slika 2: a) Področje CNC struženja z vpetim obdelovancem, b) kontrolna plošča CNC stružnice AERO TURN BT-380 s sistemom FANUC Serije 0i-TC, c) izgled obdelovanca (vzorca) na katerem so bili izvršeni preizkusi struženja 


\section{RESULTS AND DISCUSSION}

To determine the dependence of $T=\mathrm{f}\left(v_{\mathrm{c}}\right)$ we must satisfy the condition $v_{\mathrm{cmax}}=2.5 v_{\mathrm{cmin}}$ and the cutting-tool wear criteria of $V B_{\mathrm{k}}=0.2 \mathrm{~mm}$. The scheme of the gradual removal of material during the turning in the virtual interface of the CATIA V5 Lathe Machining system is shown in Figure 5. The turning tests were carried out for the following values of the cutting speeds $v_{\mathrm{c} 1}=250 \mathrm{~m} \mathrm{~min}^{-1}, v_{\mathrm{c} 2}=200 \mathrm{~m} \mathrm{~min}^{-1}, v_{\mathrm{c} 3}=150 \mathrm{~m} \mathrm{~min}^{-1}$, and the cutting speed $v_{\mathrm{c} 4}=100 \mathrm{~m} \mathrm{~min}^{-1}$ was determined by the calculation method. The $\mathrm{CNC}$ machine tool calculates $v_{\mathrm{c}}=$ const. directly from the turning diameter. For the average diameter $\varnothing 58$ the cutting speed $v_{\mathrm{c}}=250$ $\mathrm{m} \mathrm{min}{ }^{-1}$ and the spindle speed $n=1348 \mathrm{~min}^{-1}$. For the maximum removed diameter the cutting speed $v_{\mathrm{c}}=254$ $\mathrm{m} \mathrm{min}{ }^{-1}$. With each cut the spindle speed of the CNC machine tool also changes. With a change of the diameter from $\varnothing 60 \mathrm{~mm}$ to $\varnothing 30 \mathrm{~mm}$ there is also a change of the feed velocity $v_{\mathrm{f}}$. Even the machining time for one cut also changes as follows.

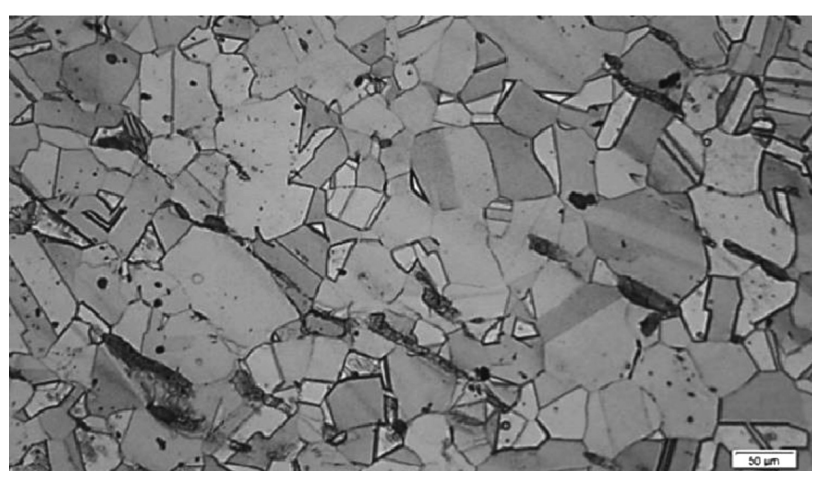

Figure 3: The microstructure of DIN 1.4301 (AISI 304) with an austenitic structure. The microstructure consists of large grains of austenite (grey) and small grains of carbides (black). ${ }^{13}$

Slika 3: Avstenitna mikrostruktura jekla DIN 1.4301 (AISI 304). Mikrostruktura je sestavljena iz velikih zrn avstenita (sive barve) in majhnih karbidnih zrn (črne barve). ${ }^{13}$

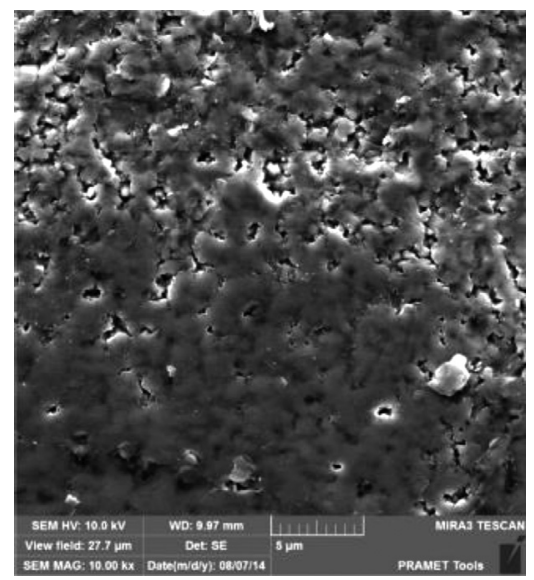

Figure 4: Surface morphology of the CNMG 120408E-FM carbide cutting insert (edge) surface appearance, SEM image

Slika 4: SEM-posnetek morfologije površine CNMG 120408E-FM karbidnega rezalnega vložka (rob)
Different criteria can be used for the measurement of tool life such as the average of the maximum flank wear, the surface roughness and the number of components per tool. In this experimental investigation the criterion of an average flank wear $V B=0.2 \mathrm{~mm}$ was considered for the tool-life measurement. Fernández-Abbia et al. ${ }^{1,2}$ reported that the cutting speed in the range of 200 to $300 \mathrm{~m} \mathrm{~min}^{-1}$ is favourable for the machining of 1.4301 stainless steel. After each pass, the cutting insert was used for a measurement of the tool wear and thus wear progress was obtained. Figure 6 shows the tool-life curves at $(150,200,250) \mathrm{m} \mathrm{min}^{-1}$ cutting speed for a constant feed rate and depth of cut. The tool life demonstrates three wear stages. Flank wear VB of carbide insert at $v_{\mathrm{c} 2}=200$ $\mathrm{m} \mathrm{min}{ }^{-1}$ can be seen in Figure 7.

Table 1: The calculation table to determine the tool life $T$ (min) Tabela 1: Tabela za izračun časa $T(\min )$ zdržljivosti orodja

\begin{tabular}{|c|c|c|c|c|c|c|}
\hline$N$ & $v_{\mathrm{ci}}$ & $T_{\mathrm{i}}$ & $\log v_{\mathrm{ci}}$ & $\log T_{\mathrm{i}}$ & $\begin{array}{c}\log v_{\mathrm{ci}} \cdot \\
\log T_{\mathrm{i}}\end{array}$ & $\log v_{\mathrm{ci}}{ }^{2}$ \\
\hline 1 & 150 & 48.8 & 2.17609 & 1.68842 & 3.67416 & 4.73537 \\
\hline 2 & 200 & 28.9 & 2.30103 & 1.46090 & 3.36157 & 5.29474 \\
\hline 3 & 250 & 19.5 & 2.39794 & 1.29003 & 3.09343 & 5.75012 \\
\hline$\sum$ & - & - & 6.87506 & 4.43935 & 10.12915 & 15.77998 \\
\hline
\end{tabular}

Auxiliary calculation $\left(\Sigma \log v_{\mathrm{ci}}\right)^{2}=6.87506^{2}=47.2664$

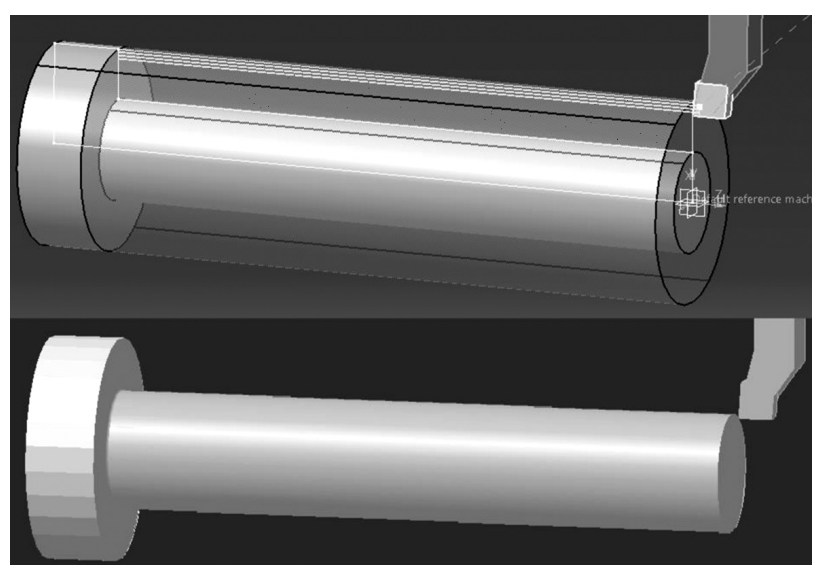

Figure 5: 3D simulation of the longitudinal turning process in CATIA Slika 5: CATIA tridimenzionalna simulacija vzdolžnega procesa struženja

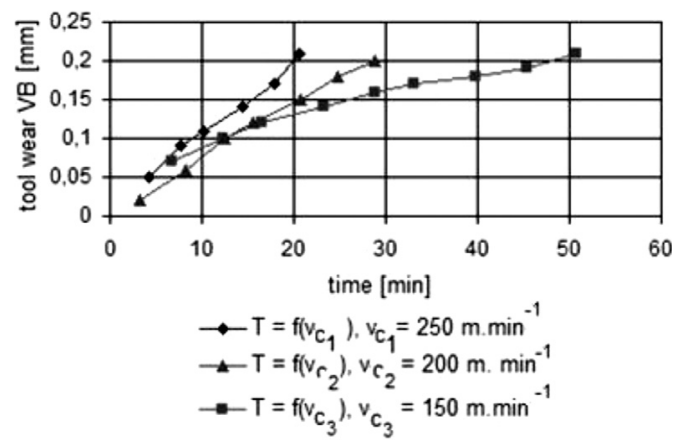

Figure 6: The graphical dependence of the tool flank wear on the machining time during the turning of DIN 1.4301

Slika 6: Grafična odvisnost obrabe boka orodja od časa struženja jekla DIN 1.4301 


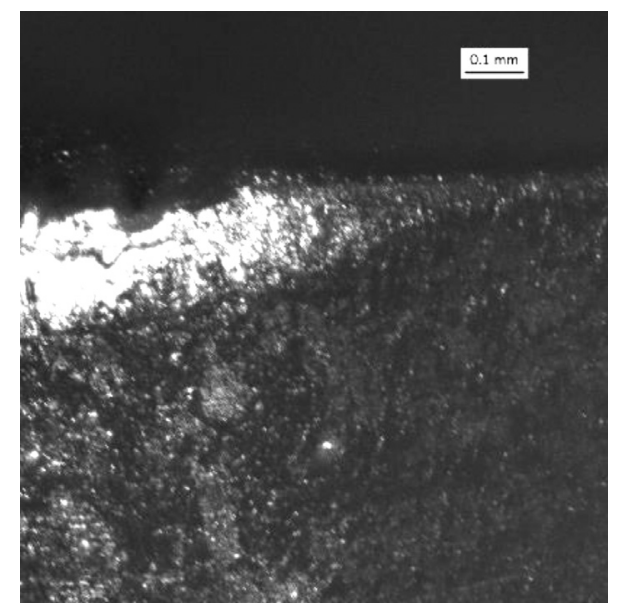

Figure 7: Flank wear $V B$ of cemented carbide insert at cutting speed $v_{\mathrm{c} 2}=200 \mathrm{~m} \mathrm{~min}^{-1}$, established criterion of the flank wear $V B=0.2 \mathrm{~mm}$ Slika 7: Obraba roba $V B$ karbidnega vložka pri hitrosti rezanja $v_{\mathrm{c} 2}=$ $200 \mathrm{~m} \mathrm{~min}^{-1}$, uveljavljeno merilo za obrabo roba $V B=0,2 \mathrm{~mm}$

In the process of investigating the quality indicators in terms of the surface integrity during the turning of 1.4301 austenitic stainless steel, the authors of the article also dealt with the dependence of the arithmetic mean surface roughness $R a=f\left(v_{\mathrm{c}}\right)$ in changing the fillet radius of the used cutting tool (the difference can see in Figure 8). The surface roughness measurement was carried out on the machined surfaces using a Taylor Hobson measuring device. The value reported represents the average of the surface roughness value obtained from at least three measurements. The surface quality of the machined surface is mainly dependent on the used cutting conditions and it plays a significant role in the functionality and fatigue life of the component.

The measured spindle speeds $n_{\mathrm{i}}$, the feed velocity rates $v_{f i}$ and the machining times for the individual cuts were determined from a calculation. Sample no. 4 was machined with the same method and with the same cutting parameters as the sample no. 3. Flank wear control was carried out after $23.3 \mathrm{~min}, 28.8 \mathrm{~min}$, and 33.06 min, and then the sample no. 5 was machined with a

Graphical dependence $R \mathbf{R}=\mathbf{f}\left(\mathbf{v}_{\mathrm{c}}\right)$

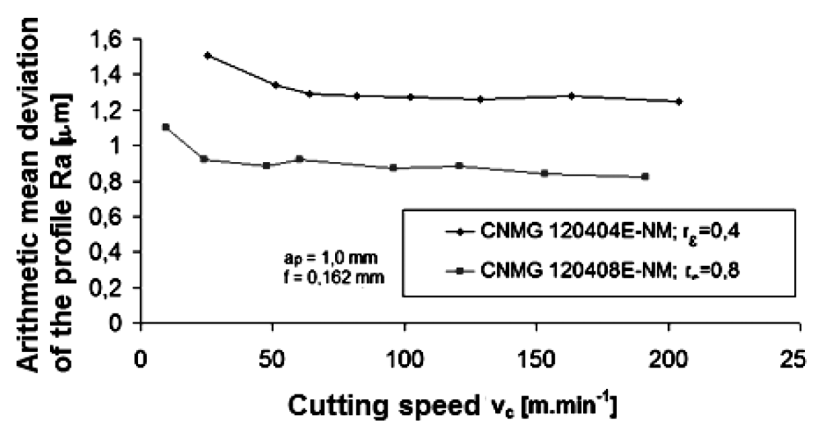

Figure 8: The graphical dependence $R a=f\left(v_{\mathrm{c}}\right)$ in the turning of DIN 1.4301 steel with CNMG $12048 \mathrm{E}$ with different $r_{\varepsilon}$

Slika 8: Grafična odvisnost $R a=f\left(v_{\mathrm{c}}\right)$ pri struženju jekla DIN 1.4301 z CNMG 12048E, z različnimi $r_{\varepsilon}$ flank wear measurement after $39.83 \mathrm{~min}, 45.33 \mathrm{~min}$, and $50.83 \mathrm{~min}$. The measured values of the flank wear $V B_{\max }$ for $v_{\mathrm{c} 1}=250 \mathrm{~m} \mathrm{~min}^{-1}, v_{\mathrm{c} 2}=200 \mathrm{~m} \mathrm{~min}^{-1}, v_{\mathrm{c} 3}=150$ $\mathrm{m} \mathrm{min}{ }^{-1}$, with $a_{\mathrm{p}}=1.0 \mathrm{~mm}$ and $f=0.15 \mathrm{~mm} / \mathrm{rev}$ are determined in this experiment. Then follows an exchange (rotation) of the cutting insert again. Then continued the completion of the turning of sample no. 5 from the diameter $\varnothing 40 \mathrm{~mm}$ to the diameter $\varnothing 30 \mathrm{~mm}$ on the $L=$ $180 \mathrm{~mm}$ with $v_{\mathrm{c} 2}=200 \mathrm{~m} \mathrm{~min}^{-1}=$ const. with the same cutting parameters $a_{\mathrm{p}}=1.0 \mathrm{~mm}, f=0.15 \mathrm{~mm} / \mathrm{rev}$, with usage of coolant. The measured spindle speeds $n_{i}$, the feed velocity rates $v_{f i}$ and the machining times for the individual cuts were determined using a calculation. During this phase of the experiment we turned samples no. 5, 6, 7, and 8 from the overall number of 10 pieces. The graphical dependence of the cutting tool wear on the machining time for the cutting speeds $v_{\mathrm{c} 1}, v_{\mathrm{c} 2}, v_{\mathrm{c} 3}$ from the turning of austenitic stainless steel 1.4301 with a cutting parameter depth of cut $a_{\mathrm{p}}=1.0 \mathrm{~mm}$ and feed rate $f=0.15$ $\mathrm{mm} / \mathrm{rev}$, with coolant is shown in Figure 6. Three points of the measurement in the dependence $T=f\left(v_{\mathrm{c}}\right)$ according to the relevant equation and determines the shape of the curve as linear in the logarithmic coordinates. For the calculation we used values directly from Table 1. The PRAMET Tools (Sandvik Group Sweden) is recommended for the tool life of the cemented cutting inserts with the coating type GC 2025 at the cutting speed $v_{\mathrm{c}}=$ $250 \mathrm{~m} \mathrm{~min}^{-1}$ with the value of tool life $T=18 \mathrm{~min}$, establishing the criterion of wear $V B_{\mathrm{k}}=0.2 \mathrm{~mm}$. Since the cemented carbide insert type GC 2025 has a multilayer coating $\mathrm{TiN}+\mathrm{Al}_{2} \mathrm{O}_{3}+\mathrm{TiC}$ on the fine-grained substrate $\mathrm{WC}+\mathrm{Co}$ it achieves an even higher durability.

There is an analytical description for determining the dependence of the tool life $T=f\left(v_{\mathrm{c}}\right)$ with a value of $v_{\mathrm{c}}=$ $100 \mathrm{~m} \mathrm{~min}^{-1}$ in the following section. The linear regression of the single parameter is:

$$
\hat{y}=b_{0} \cdot x_{0}+b_{1} \cdot x_{1}
$$

Then the $x_{0}$ is a fictitious value, which has a value of 1 for the integer scale. For the logarithmic scale of $\log 10$ $=1$, the $x_{1}$ is an independent variable, the $b_{0}$ is an additive constant, which shows the growth on the axis " $y$ ", and the $b_{1}$ indicates the slope of the regression function. The values $b_{0}, b_{1}$ are then calculated using the following Equation (2) $(x)$ to $(y)$ :

$$
b_{1}=\frac{N \cdot \sum_{i=1}^{N}\left(\lg T_{i} \cdot \lg v_{\mathrm{c}_{i}}\right)-\sum_{i=1}^{N} \lg T_{i} \cdot \sum_{i=1}^{N} \lg v_{\mathrm{c}_{i}}}{N \cdot \sum_{i=1}^{N}\left(\lg ^{2} v_{\mathrm{c}_{i}}\right)-\left(\sum_{i=1}^{N} \lg v_{\mathrm{c}_{i}}\right)^{2}}
$$

Substituting $b_{1}$ into the Equation (2) we obtain the constant $b_{0}$, Equation (3):

$$
b_{0}=\frac{\sum_{i=1}^{N} \lg T_{i}-b_{1} \sum_{i=1}^{N} \lg v_{\mathrm{c}_{i}}}{N}
$$

where $i$ to $N$ is the number of measurements 


$$
\begin{gathered}
b_{1}=\frac{3 \cdot(10.12915)-(4.43935 \cdot 6,87506)}{3 \cdot 15.77998-47.2664}=-1.81327 \\
b_{0}=\frac{4.43935-(-1.81327) \cdot 6.87506}{3}=5.63523 \\
\hat{y}=b_{0} \cdot x_{0}+b_{1} \cdot x_{1}=5.63523 \cdot x_{0}-1.81327 \cdot x_{1}
\end{gathered}
$$

The introduction of the substitution for $b_{0}=\log C_{\mathrm{T}}$ and for $\hat{y}=\log T$ is then $C_{\mathrm{T}}=10^{5,63523}=431,748.10^{3}$. Then the value is $\operatorname{tg} \alpha=1.81327$, thereof $\alpha=\operatorname{arctg} 1.81327$ and consequently the size of the angle is $\alpha=61^{\circ} 21^{\prime}$. The inclination angle of the line in the logarithmic coordinates is $-b_{1}=m=\operatorname{tg} \alpha$, and from which we obtain the value of the angle $\alpha$.

The shape of the linear regression for the tool life has the following form:

$$
\log T=\log C_{\mathrm{T}}-m \log v_{\mathrm{c}}
$$

The equation according to Taylor (2) for the material 1.4301 (AISI 304) will be in the following form for the cutting conditions $a_{\mathrm{p}}=1 \mathrm{~mm}$ and $f=0.15 \mathrm{~mm} / \mathrm{rev}$.

$$
T=\frac{431.748 \cdot 10^{3}}{v_{c}^{1.81327}}
$$

Then for the tool-life calculation of cutting edge for the cutting speed $v_{\mathrm{c} 4}=100 \mathrm{~m} \mathrm{~min}^{-1}$ the following formula is used:

$$
\frac{T_{4}}{T_{1}}=\left(\frac{v_{c_{1}}}{v_{c_{4}}}\right)^{m} \text { then } T_{4}=19.5\left(\frac{250}{100}\right)^{1.81327}=102.7 \mathrm{~min}
$$

\section{CONCLUSIONS}

The main aim of the presented paper is an experimental determination of the tool life depending on the cutting speed according to Taylor in turning the austenitic stainless steel 1.4301 (AISI 304). The cutting speed and the feed rate have a significant effect on the flank wear. The tool life is significantly influenced by the cutting parameters, the surface roughness and the flank wear. The obtained results are statistically processed using a linear regression analysis with the method of least squares. The results and values are shown in Table 1, and the graphical dependence of the flank wear $V B_{\mathrm{k}}$ on the time is shown in Figure 6. The flank wear (Figure 7) and the tool life of the cemented carbide insert were monitored so that there is no reduction in the quality of the surface finish. These areas were defined by the technical documentation. For the cemented carbide insert wear always occurs at one point when there is a variable depth of cut (can see in Figure 7). For example, this can be avoided by using of the CNC program preparation in the three-dimensional CATIA interface (Figure 5). The CNC program divides the allowance for machining so that the next depth of cut was slightly smaller than the previous one. The advantage of this cycle is the fact that the cutting tool is not still loaded in the same area, but over the range of applied depth of cuts. When machining austenitic stainless steels we should follow these rules, which help to increase the durability of the cutting edge of the carbide cutting tool and thus the quality of the machined surface.

- The first rule is basically to use cutting inserts coated with CVD+PVD (for example, $\mathrm{TiC}+\mathrm{Al}_{2} \mathrm{O}_{3}+\mathrm{TiN}$ on the cutting tool surface).

- The second is to use a washer of cemented carbide directly below the cemented carbide inserts.

- The third rule is to visually diagnose and timely eliminate the causes of premature damage to the cutting edge (notch).

- The fourth rule is to use the best applications for the changeable cutting inserts for dimensionally demanding workpieces.

In terms of the defined cutting parameters the greatest impact comes from the cutting speed $v_{\mathrm{c}}$, a lower feed rate $f$ and the least depth of cut $a_{\mathrm{p}}$. We did not study more tool life depending $T=f(f)$ and $T=f\left(a_{\mathrm{p}}\right)$ for this reason in CNC machine tools, and the size of the observed flank wear. This creates space for the realization of further research in this area. The applied, discovered knowledge from the literature sources and the experiments conducted here can be used in the future for the manufacture of specific parts on CNC machine tools with new, progressive cutting tools.

\section{Acknowledgement}

This paper was supported in the frame of the project "Alexander Dubček University of Trenčín - Faculty of special technology wants to offer high-quality and modern science/research and education", ITMS code 26110230099, based on the Operational Programme Education. Modern education for knowledge society / The project is co-funded by European Social Fund and also includes the results of the grant VEGA no. 1/9428/02 titled "The technological heredity of the machined surfaces - surface integrity".

\section{REFERENCES}

${ }^{1}$ A. I. Fernández-Abia, J. Barreiro, J. Fernández-Larrinoa, L. N. López de Lacalle, A. Fernández-Valdivielso, O.M. Perreira, Behaviour of PVD coatings in the turning of austenitic stainless steels, Procedia Engineering, 63 (2013), 133-141, doi:10.1016/j.proeng. 2013.08.241

${ }^{2}$ A. I. Fernández-Abia, J. Barreiro, L. N. López de Lacalle, S. Martínez, Effect of very high cutting speeds on shearing, cutting forces and roughness in dry turning of austenitic stainless steels, International Journal of Advanced Manufacturing Technology, 57 (2011) 1-4, 61-71, doi:10.1007/s00170-011-3267-9

${ }^{3}$ M. A. Xavior, M. Adithan, Determining the influence of cutting fluids on tool wear and surface roughness during turning of AISI 304 austenitic stainless steel, Journal of Material Processing Technology, 209 (2009) 2, 900-909, doi:10.1016/j.jmatprotec.2008.02.068

${ }^{4}$ A. P. Kulkarni, G. G. Joshi, V. G. Sargade, Dry turning of AISI 304 austenitic stainless steel using AlTiCrN coated insert produced by HPPMS technique, Procedia Engineering, 64 (2013), 737-746, doi:10.1016/j.proeng.2013.09.149 
${ }^{5}$ S. S. Wagh, A. P. Kulkarni, V. G. Sargade, Machinability studies of austenitic stainless steel (AISI 304) using PVD cathodic arc evaporation (CAE) system deposited AlCrN/TiAlN coated carbide inserts, Procedia Engineering, 64) (2013), 907-914, doi:10.1016/j.proeng. 2013.09.167

${ }^{6}$ S. Emura, M. Kawajiri, X. Min, S. Yamamoto, K. Sakuraya, K. Tsuzaki, Machinability improvement and its mechanism in SUS304 austenitic stainless steel by precipitated hexagonal boron nitride, ISIJ International, 53 (2013) 10, 1841-1849, doi:10.2355/isijinternational.53.1841

${ }^{7}$ J. Paro, H. Hänninen, V. Kauppinen, Tool wear and machinability of X5CrMn18 stainless steel, Journal of Materials Processing Technology, 119 (2001) 1-3, 14-20, doi:10.1016/S0924-0136(01) 00877-9

${ }^{8}$ F. Koné, C. Czarnota, B. Haddag, M. Nouari, Modeling of velocity-dependent chip flow angle and experimental analysis when machining 304L austenitic stainless steel with groove coated-carbide tools, Journal of Materials Processing Technology, 213 (2013) 7, 1166-1178, doi:10.1016/j.jmat-protec.2013.01.015

${ }^{9}$ S. E. Cordes, Thermal stability of $\gamma$-alumina PVD coatings and analysis of their performance in machining of austenitic stainless steels, CIRP Journal of Manufacturing Science and Technology, 5 (2012) 1, 20-25, doi:10.1016/j.cirpj.2011.11. 003

${ }^{10}$ R. Čep, A. Janásek, A. Slíva, M. Neslušan, M. Binder, Experimental tool life tests of indexable inserts for stainless steel machining, Tehnicki Vjesnik, 20 (2013) 6, 933-940

${ }^{11}$ V. T. G. Naves, M. B. Da Silva, F. J. Da Silva, Evaluation of the effect of application of cutting fluid at high pressure on tool wear during turning operation of AISI 316 austenitic stainless steel, Wear, 302 (2013) 1-2, 1201-1208, doi:10.1016/j.wear.2013.03.016

${ }^{12}$ A. I. Fernández-Abia, J. Barreiro, L. N. López de Lacalle, S. Martínez-Pellitero, Behavior of austenitic stainless steels at high speed turning using specific force coefficients, International Journal of Advanced Manufacturing Technology, 62 (2012) 5-8, 505-515, doi:10.1007/s00170-011-3846-9

${ }^{13}$ R. K. C. Nkhoma, C. W. Siyasiya, W. E. Stumpf, Hot workability of AISI 321 and AISI 304 austenitic stainless steels, Journal of Alloys and Compounds, 595 (2014), 103-112, doi:10.1016/j.jallcom.2014. 01.157

${ }^{14} \mathrm{~J}$. Jambor, Improving the quality of the machining process through new technologies, Annals of DAAAM for 2012 \& Proceedings World Symposium Intelligent Manufacturing \& Automation, 23 2012, 623-626
${ }^{15}$ Z. Tekiner, S. Yesilyurt, Investigation of the cutting parameters depending on process sound during turning of AISI 304 austenitic stainless steel, Materials and Design, 25 (2004) 6, 507-513, doi:10.1016/j.matdes.2003.12.011

${ }^{16}$ T. Akasawa, H. Sakurai, M. Nakamura, T. Tanaka, K. Takano, Effects of free-cutting additives on the machinability of austenitic stainless steels, Journal of Materials Processing Technology, 143-144 (2003) 1, 66-71, doi:10.1016/S0924-0136(03)00321-2

${ }^{17}$ M. Kaladhar, K. Venkata Subbaiah, C. Srinivasa Rao, Parametric optimization during machining of AISI 304 austenitic stainless steel using CVD coated Duratomic ${ }^{\mathrm{TM}}$ cutting insert, International Journal of Industrial Engineering Computations, 3 (2012) 4, 577-586, doi:10.5267/j.ijiec. 2012.04.002

${ }^{18}$ M. Aydin, C. Karakuzu, M. Uçar, A. Cengiz, M. A. Cavuşlu, Prediction of surface roughness and cutting zone temperature in dry turning processes of AISI304 stainless steel using ANFIS with PSO learning, Int. Journal of Advanced Manufacturing Technology, 67 (2013) 1-4, 957-967, doi:10.1007/s00170-012-4540-2

${ }^{19}$ I. Korkut, M. Kasap, I. Ciftci, U. Seker, Determination of optimum cutting parameters during machining of AISI 304 austenitic stainless steel, Materials and Design, 25 (2004) 4, 303-305, doi:10.1016/ j.matdes.2003.10.011

${ }^{20}$ I. Ciftci, Machining of austenitic stainless steels using CVD multilayer coated cemented carbide tools, Tribology International, 39 (2006) 6, 565-569, doi:10.1016/j.triboint. 2005.05.005

${ }^{21} \mathrm{~W}$. Grzesik, The role of coatings in controlling the cutting process when turning with coated indexable inserts, Journal of Material Processing Technology, 79 (1998) 1-3, 133-143, doi:10.1016/S09240136(97)00491-3

${ }^{22}$ A. Hosokawa, T. Ueda, R. Onishi, R. Tanaka, T. Furumoto, Turning of difficult-to-machine materials with actively driven rotary tool, CIRP Annals - Manufacturing Technology, 59 (2010) 1, 89-92, doi:10.1016/j.cirp.2010.03.053

${ }^{23}$ W. I. H. Liew, B. K. A. Ngoi, Y. G. Lu, Wear characteristics of PCBN tools in the ultra-precision machining of stainless steel at low speeds, Wear, 254 (2003) 3-4, 265-277, doi:10.1016/S0043-1648 (03)00002-4

${ }^{24}$ M. Hua, W. Xicheng, L. Jian, Friction and wear behaviour of SUS 304 austenitic stainless steel against $\mathrm{Al}_{2} \mathrm{O}_{3}$ ceramic ball under relative high load, Wear, 265 (2008) 5-6, 799-810, doi:10.1016/j.wear. 2008.01.017 